\title{
DIMENSI TRANSENDENSI DALAM NOVEL BUMI CINTA KARYA HABIBURRAHMAN EL SHIRAZY
}

\author{
DIMENSION OF TRANSENDENCE IN BUMI CINTA NOVEL BY HABIBURRAHMAN EL \\ SHIRAZY
}

\section{Fatmawati; Andayani; Raheni Suhita}

Fakultas Keguruan dan Ilmu Pendidikan, Universitas Sebelas Maret Jalan Ir Sutami 36 A Kentingan, Jebres, Surakarta, Jawa Tengah, Indonesia fatmawati45_8@student.uns.ac.id; bu_and09@yahoo.co.id; raheni_suhita@yahoo.com

(Naskah diterima tangga 1 Desember 2019, direvisi terakhir tanggal 29 September 2021, dan disetujui tanggal 26 November 2021)

DOI: https:// doi.org/10.26499/wdprw.v49i2.425

\begin{abstract}
This study aims to describe the dimension of transcendence in the Bumi Cinta novel by Habiburrahman El Shirazy. The data of this research are sentences from the Bumi Cinta novel text which contains a transcendence dimension. The identification of the text of the transcendence dimension, giving meaning, as well as careful exploration of the meaning is carried out using the hermeneutic method. The results of the research are as follows: First, there are three elements of transcendence in the Bumi Cinta novel, namely (1) recognition of human dependence on God seen from worship rituals in the form of prayer and remembrance, (2) there is an absolute difference between God and humans, and (3) the acknowledgment of absolute norms from God that do not come from human reason. Second, the transcendence dimension as the basis for humanization and liberation activities.
\end{abstract}

Keywords: transcendence dimension; bumi cinta novel; hermeneutics

\begin{abstract}
Abstrak
Penelitan ini bertujuan untuk mendeskripsikan dimensi transendensi dalam novel Bumi Cinta karya Habiburrahman El Shirazy. Data penelitian ini ialah kalimat-kalimat dari teks novel Bumi Cinta yang mengandung dimensi transendensi. Pengidentifikasian teks dimensi transendensi, pemberian makna, serta penggalian cermat atas makna dilakukan dengan menggunakan metode hermeneutika. Hasil penelitiannya ialah sebagai berikut: Pertama, terdapat tiga unsur transendensi dalam novel Bumi Cinta, yakni (1) pengakuan tentang ketergantungan manusia pada Tuhan dilihat dari ritual ibadah dalam bentuk doa dan zikir, (2) ada perbedaan mutlak antara Tuhan dan manusia, dan (3) pengakuan adanya norma-norma mutlak dari Tuhan yang tidak berasal dari akal manusia. Kedua, dimensi transendensi sebagai dasar kegiatan humanisasi dan liberasi.
\end{abstract}

Kata-kata kunci: dimensi transendensi; novel bumi cinta; hermeneutika

\section{Pendahuluan}

Transendensi memberi pemahaman berupa kesadaran manusia akan Tuhan (Roqib, 2011: 69). Dengan pemahaman itu, diharapkan manusia dapat selalu membangun hubungan yang erat dengan Tuhan, juga makhluk-Nya.
Hal tersebut akan berdampak pada nilai-nilai ketuhanan menjadi sesuatu yang tidak terpisahkan dari kehidupan manusia. Dimensi transendensi menjadi puncak dari kesadaran manusia, puncak inilah yang akan menyelaraskan kesadaran manusia dengan 
perilakunya. Dimensi transendensi memberikan arahan nilai religiousitas sehingga manusia dapat terhubung dengan Tuhan, selanjutnya akan terimplementasi dalam kehidupan sehari-hari dalam wujud liberasi dan humanisasi. Misalnya, liberasi dalam konteks kemiskinan; ada dua pilihan antara membebaskan kemiskinan struktural yang dilakukan dengan cara menghancurkan para penguasa kekayaan, atau liberasi yang menciptakan sistem ekonomi yang berkeadilan. Islam lebih memilih cara yang kedua. Dalam hal yang demikian, Islam menunjukkan atau menghendaki adanya transformasi struktural.

Kita tahu bahwa proses membangun peradaban dimulai dari kesadaran bahwa nilai-nilai religiousitas dan keimanan merupakan bagian yang sangat vital, bagian yang tidak bisa dipisahkan. Hal itu akan membuat kita merasakan rahmat Tuhan dengan Dunia-Nya. Kita akan kembali hidup dengan suasana yang lepas dari ruang dan waktu kala bersentuhan dengan kebesaran Tuhan (Kuntowijoyo, 1991: 289). Tujuan transendensi ialah ingin membersihkan kita dengan cara mengingatkan bahwa nilai-nilai transendental ialah keniscayaan dari fitrahnya manusia.

Nilai-nilai transendental pada sistem pengetahuan masyarakat saat ini menjadikan optimisme terhadap peradaban postmodernisme. Hal itu karena modernisme yang lahir dari renaissance telah memisahkan agama dari ilmu pengetahuan. Akhirnya modernisme menimbulkan ketaktenangan (distabilitas). Manusia modern yang lahir dari rahim renaissance menjadi manusia antroposentris, yang menganggap bahwa manusialah sentralnya dunia, bukan Tuhan, merasa cukup dengan dirinya sendiri, karena manusia ialah makhluk yang berakal (Asy, 2018). Hal demikian mengindikasikan adanya praktik hidup yang tidak mempercayai adanya Tuhan sebagai penguasa semesta. Renaissance melakakukan differentiation, yang artinya memisahkan antara agama dan dunia, humanisme, dan sekulerisme (Kuntowijaya, 2006: 22).

Sampai zaman postmodernisme ini pun peradaban barat tetap melakukan sekulerisme sekalipun reaksi agama-agama berbedabeda. Dalam hal ini Roger Garaudy menyatakan bahwa sampai saat ini filsafat barat terombang-ambing antara kubu idealis atau kubu materialis. Dia menganjurkan supaya barat yang telah "membunuh" Tuhan itu kembali kepada filsafat kenabian dan mengakui wahyu (Garaudy, 1982: 142).

Problematika itu dapat diselesaikan dengan dimensi transendensi. Hal demikian didasarkan pada peranan penting dari transendensi. Transendensi memberikan makna kehidupan, yang nantinya akan menuntun manusia menuju nilai-nilai luhur kemanusiaan. Transendensi hadir untuk mewujudkan prinsip-prinsip yang bersifat universal, dan sebagai tuntunan/petunjuk bagi manusia secara keseluruhan (Hanafi, 2007: 7).

Transendensi merupakan salah satu elemen penting dalam sastra profetik yang digagas oleh Kuntowijaya. Sastra profetik bermaksud melampui keterbatasan akal pikiran manusia dan mencapai pengetahuan yang lebih tinggi. Dengan demikian, sastra profetik mengacu kepada understanding dan interpretasi kitab-kitab suci berdasar realitas (Kuntowijaya: 2006: 2). Aliran sastra semacam ini disebut dengan sastra transendental. Aliran sastra ini bermaksud untuk memosisikan manusia yang berkewajiban atas kehidupan yang lebih bermakna.

Salah satu contoh sastra transendental ialah novel Bumi Cinta yang ditulis oleh Habiburrahman El Shirazy. Hal demikian disandarkan bahwa novel yang ditulis oleh penulis yang biasa disapa Kang Abik ini merupakan hasil dari tadabur ayat-ayat AlQuran dengan melihat realitas yang 
berkembang di tengah-tengah kehidupan masyarakat. Beliau menuliskan novel ini dengan tujuan menjadikannya sebagai sarana dalam rangka membumikan Al-Quran. Karya-karya Kang Abik ini selalu hadir dengan value inspiratif sebagai karya pembangun jiwa bagi penikmatnya (pembaca).

Novel ini menarik untuk diteliti karena menggambarkan suatu fenomena yang terjadi di kota Moskwa, Rusia, sebuah negara yang dikenal sebagai negeri yang sebagian besar penduduknya menjunjung tinggi free sex radikal, negeri yang juga berpaham komunisme. Penggambaran fenomena di Rusia ini, sedikit tidaknya merepresentasikan fenomena yang ada di Indonesia. Di era globalisasi ini, zamannya orang-orang mengagungkan gaya hidup modern, menjadi suatu ujian yang amat berat bagi orang-orang mukmin. Free sex dan pergaulan bebas sudah menjadi tren bagi muda-mudi saat ini. Sebuah media di Jakarta menuliskan berita bahwa $21 \%$ remaja Indonesia anut seks bebas (https:/ / www.inilahkoran.com/berita/19867 /honestdocs-21-remaja-indonesia-anut seksbebas). Selain itu, novel ini menarik untuk diteliti karena mengandung nilai-nilai yang bersifat universal.

Penelitian ini mendeskripsikan dimensi transendensi yang terdapat dalam novel Bumi Cinta. Terhadap dimensi transendensi dalam karya sastra, telah ada penelitian sebelumnya, yakni penelitian Wirawan (2018) dengan judul "Dimensi Transendensi dalam Antologi Puisi Rahasia Sang Guru Sufi Karya Odhy's". Penelitian Wirawan ini bertujuan mendeskripsikan makna etika profetik dalam antologi puisi Rahasia Sang Guru Sufi karya Odhy's ditinjau dari dimensi transendensi. Penelitian itu menggunakan hermeneutika Rifatere. Kesimpulan dari penelitian tersebut adalah sebagai berikut. Pertama, terkandung dimensi transendental dalam puisi-puisi karya Odhy's. Kedua, Odhy's sebagai penyair secara konsisten menggunakan pilihan kata (diksi) yang khas akan sufistik. Contohnya, terdapat diksi mawar, setanggi, samudera, taman, kolam, burung, zikir, sang guru, tarikat, makrifat, mabuk, anggur, cermin, kematian dan lain sebagainya. Ketiga, 44 judul puisi karya Odhy's dikelompokkan ke dalam puisi transendensi (Wirawan 2018).

Penelitian novel Bumi Cinta sebelumnya telah dilakukan, salah satunya ialah penelitian Alimatussa'diyah dan Nuryatin (2017) dengan judul "Inferioritas Tokoh Perempuan dalam Novel Bumi Cinta Karya Habiburrahman El Shirazy". Penelitian tersebut menyimpulkan, pertama, gambaran tokoh perempuan yang direpresentasikan pengarang melalui dimensi fisiologis, psikologis, serta sosiologis menggunakan cara langsung dan tidak langsung; kedua, inferioritas yang dialami tokoh perempuan disebabkan faktor intern (dalam diri) dan faktor ekstern berupa kekerasan yang dialami tokoh perempuan; ketiga, kompensasi yang dilakukan tokoh perempuan berupa kompensasi menarik diri dan agresif; dan keempat, kajian dari segi feminis menunjukkan masih adanya dominasi dari tokoh laki-laki terhadap tokoh perempuan (Alimatussa'diyah dan Nuryatin: 2017).

\section{Metode}

Penelitian dimensi transendensi dalam novel Bumi Cinta karya Habiburrahman El Shirazy ini merupakan penelitian kualitatif. Penelitian kualitatif ialah penelitian yang bermaksud untuk memahami fenomena tentang apa yang dialami oleh subjek penelitian secara holistik, dan dengan cara mendeskripsikan dalam bentuk kata-kata dan bahasa (Moleong, 2016: 6). Penelitian ini berhubungan dengan cara penelitian yang bersifat mempertanyakan bagaimanakah dimensi transendensi dalam novel Bumi Cinta karya Habiburrahman El Shirazy.

Penelitian ini menggunakan kajian hermeneutika interpretasi Paul Ricoeur sebagai landasan metodelogisnya. Jika dilihat 
dari cara kerjanya, hermeneutika ialah teori tentang bekerjanya pemahaman dalam menafsirkan teks (Ricoeur, 2006: 57). Hermeneutika mengarahkan perhatian kepada makna objektif dari teks, terlepas dari makna subjektif pengarang. Dengan demikian, teks itu otonom, ia berada di posisi tengah, antara penjelasan struktural, dan pemahaman hermeneutika (Ricoeur, 2012: 59-60). Kedua hal ini mengalami dikotomi. Penyebab dikotomi ini ialah penjelasan struktural memiliki sifat objektif, sedangkan pemahaman hermeneutika bersifat subjektif. Dengan demikian, dikotomi ini mesti diselesaikan (Sumaryono, 1999: 108-110).

Teknik pelaksanaan penelitian dilakukan dengan cara sebagai berikut. Pertama, melakukan pembacaan teks yang dikenal dengan istilah dekontekstualisasi. Cara ini bertujuan untuk memelihara atau menjaga otonomi teks tatkala interpreter melakukan pemahaman terhadap teks. Kedua, rekontekstualisasi. Tujuan dari tahapan ini adalah untuk melihat kembali latar belakang bagaimana terjadinya teks dan sebagainya. Dengan demikian, teks 'melepaskan diri' dari cakrawala yang terbatas pada pengarangnya. Hal itu disebut dengan istilah kontekstualisasi. Selanjutnya teks membuka diri terhadap kemungkinan dan ditafsirkan dengan luas oleh pembaca yang berbeda (Wachid: 2006).

Tahapan yang dilakukan, yaitu (1) simbolik, yakni pemahaman dari simbol-simbol, mengidentifikasi teks dimensi transendensi yang terekspresikan melalui simbol-simbol; dalam novel Bumi Cinta; (2) pemberian makna dari simbol yang telah diidentifikasi, lalu menggali secara cermat maknanya. Tahap kedua ini sekaligus sebagai langkah filosofis, yaitu penafsir berpikir dengan menggunakan simbol sebagai titik-toloknya.

\section{Hasil dan Pembahasan}

Transendensi merupakan salah satu elemen penting dalam sastra profetik yang digagas oleh Kuntowijaya. Bisa dikatakan bahwa dimensi transendensi ialah sepertiga dari keutuhan sastra profetik (Wirawan 2018). Gagasan ini berpijak pada dalil kitab suci AlQuran pada surah ketiga, yakni Ali Imran, Ayat 110 (Rifai, 2009). Ayat tersebut mengandung tiga elemen penting yang menjadi dasar kegiatan sastra profetik, yakni amar ma'ruf (humanisasi); nahi mungkar (liberasi); dan tu'minuna billah (transendensi) (Kuntowijaya, 2006: 8).

Transendensi bertujuan menambahkan dimensi transendental dengan cara membersihkan diri dari arus hedonisme, materialisme, dan budaya yang dekaden. Singkatnya, menghendaki manusia untuk mengakui otoritas mutlak Allah Swt. Transendensi menjelma sebagai sebuah norma aksiologis, suatu standar perilaku dan menjadi kode etik yang bersifat universal. Hal ini menjadikan dimensi transendensi sebagai basis atau dasar kegiatan kehidupan manusia. Dalam istilah dimensi profetik, transendensi ialah basis kegiatan humanisasi dan liberasi. Transendensi sebagai pengontrol perilaku dalam kehidupan manusia.

Berdasarkan penelitian terhadap dimensi transendensi novel Bumi Cinta dengan metode hermeneutika interpretasi Paul Ricoeur, novel ini menggambarkan unsur-unsur dimensi transendensi seperti yang diungkap oleh Roger Garaudy, yakni (1) pengakuan tentang ketergantungan manusia pada Tuhan; (2) ada perbedaan mutlak antara Tuhan dan manusia; dan (3) pengakuan adanya norma-norma mutlak dari Tuhan yang tak berasal dari akal manusia (Garaudy, 1982: 34). Penggambaran tiga unsur dimensi ini berlanjut pada dimensi transendensi sebagai basis kegiatan dua elemen profetik, yakni humanisasi dan liberasi. 


\subsection{Unsur Transendensi}

\subsubsection{Pengakuan Ketergantungan tentang Manusia pada Tuhan}

Pengakuan ketergantungan manusia pada Tuhan, yakni manusia menyadari bahwa dirinya hanyalah sebagai seorang hamba, segala urusannya tergantung pada Allah Swt. Oleh karena itu, manusia berdoa kepada Allah, memohon kebaikan dan keberkahan. Doa dalam paradigma Habiburrahman El Shirazy yang tertuang dalam novel Bumi Cinta menjadi perlambangan atas peristiwaperistiwa empiris. Dalam domain transendensi, segala yang jisim (kebendaan) sesungguhnya perwakilan atas eksistensi Tuhan, Allah Swt, seperti yang terdapat dalam kutipan berikut ini.

“Dan ketika alam bertasbih..." (Shirazy, 2019: 95).

Teks dalam novel tersebut menggambarkan suatu kehidupan di dunia, seperti adanya pohon-pohon, bebatuan, dan salju sebagai wujud eksistensi adanya Tuhan sebagai pencipta alam semesta, yang selalu patuh dan taat pada ketentuan dan hukum sunatullah. Penggambaran alam yang bertasbih ini sebagai sebuah simbol seperti yang tertuang dalam Al-Quran:

Semua yang ada di langit dan di bumi bertasbih kepada Allah dan dialah yang Maha Perkasa, Maha Bijaksana (Q.S. Al Hadid (57): 1)

Novel ini acapkali memunculkan teksteks yang menggambarkan sebuah ketergantungan seorang manusia sebagai hamba kepada Tuhan melalui narasi berdoa. Berdoa merupakan senjata paling ampuh bagi orangorang yang beriman (mukminin). Seperti yang diungkap oleh Uhi (2016: 85-86), bahwasanya nilai-nilai ketuhanan, umumnya, diaktualisasikan dalam bentuk doa dan ibadah, berikut kutipannya:
“...Ia berdoa kepada Allah agar menjaga diri dan imannya." (Shirazy, 2019: 50).

Ayyas di situ terpaksa harus menyantap makanan bersama Yelena. Dalam kutipan tersebut, Ayyas menyadari bahwa berduaan dengan wanita cantik yang bukan mahrom adalah sebuah ujian yang begitu besar. Teks tersebut melukiskan bahwa seorang manusia selalu bergantung pada Rabb-nya. Dalam Islam, iman seorang manusia bisa saja naik, bisa juga turun. Seorang hamba dianjurkan untuk meningkatkan amal saleh, agar iman terus naik atau minimal terjaga dari maksiat. Ikhtiar itu juga dilakukan dengan ritual berdoa. Bahwa iman seseorang juga dikendalikan oleh Allah sehingga sepatutnya manusia meminta kepada Allah untuk menjaga imannya.

"Ayyas meludah dan membaca isti'adzah...". (Shirazy, 2019: 93-94).

Manusia akan selalu mendapat gangguan dari setan. Sebab, setan telah berjanji akan selalu menggoda manusia untuk berbuat maksiat hingga hari kiamat. Teks di atas secara eksplisit mengandung unsur ketergantungan manusia kepada Tuhannya dalam menjaga dirinya agar tidak terjerambab dalam dosa dan maksiat.

“Dalam cemas dan rasa takut yang tiada terkira, ia meminta kepada Tuhan agar diberi kesempatan untuk tetap hidup..." (Shirazy, 2019: 165).

Kutipan tersebut menunjukkan ketergantungan manusia kepada Tuhan dalam segala kondisi yang dihadapi manusia. Bahkan, bagi seseorang Yelena yang sudah tidak percaya akan Tuhan dan agama sekalipun (atheis), ketika mendapati dirinya dalam sebuah kesulitan yang tidak bisa lagi dihadapi, dari relung hatinya masih meyakini bahwa ia bergantung pada Tuhan. Artinya, manusia 
akan selalu membutuhkan Tuhan. Dalam teks tersebut, secara implisit menggambarkan bahwa Yelena tengah berdoa, mengadu kepada Tuhan, ia menggantungkan harapan terakhirnya pada Tuhan.

Selain berdoa, zikir juga merupakan sesuatu yang sangat vital guna menjamah ruang transendensi yang sakral. Zikir menenangkan jiwa dan pikiran manusia. Zikir ialah nutrisi jiwa bagi orang-orang yang beriman.

"Selesai sholat Subuh, seperti biasa, ia membaca Al-Quran..." (Shirazy, 2019: 58).

Zikir menenangkan hati. Zikir melejidkan imaji transendensi dan religious experience (pengalaman religius) yang unik dan khas. Iqbal (2016: 75) mengatakan bahwa pengalaman religius sepenuhnya memuaskan pembuktian secara intelek. Hal itu berakibat kepada iradah kreatif yang terarah secara rasional agar ego individualitas ditekan pada kehadiran ego yang Mutlak, Allah Swt. Salat dan baca Al-Quran merupakan bagian dari dzikir, yakni mengingat Allah. Kegiatankegiatan yang dilakukan Ayyas ersebut terintegrasi dalam satu tujuan, yakni ketergantungan seorang manusia sebagai hamba yang ingin dijaga oleh Allah kehidupannya.

Selain itu, representasi transendensi berupa ketergantungan manusia pada Tuhan, yaitu adanya teks-teks yang mengisyaratkan adanya hal tersebut, misalnya mengucapkan basmalah yang terdapat dalam halaman 526 . Dalam teks tersebut, Linor yang ingin menemui Ayyas merasa was-was karena bisa jadi agen Solomon mengetahui keberadaanya.

Dalam Islam, sesuatu aktivitas diawali dengan membaca basmalah. Hal tersebut merupakan penggambaran penjamahan aspek transendensi, perilaku manusia selalu terhubung dengan Allah.

Selanjutnya representasi dimensi transendensi dalam novel tersebut ada yang berupa pengucapan masya Allah ketika merasakan sesuatu kekaguman. Mengucapkan insya Allah ketika berjanji. Kita harus menyadari bahwa semua peristiwa di dunia ini atas kehendak Allah Swt. Insya Allah adalah pengakuan mutlak bahwa kehidupan manusia bergantung atas ketentuan Tuhan.

Selanjutnya, mengucapkan alhamdulillah sebagai bentuk rasa syukur manusia atas nikmat yang telah Allah berikan. Nikmat yang diberikan oleh Allah Swt tak bisa dihitung. Mengucapkan hamdalah ialah bentuk mensyukuri yang dianjurkan dalam Islam.

\subsubsection{Ada Perbedaan Mutlak antara Tuhan dan Manusia}

Manusia ialah makhluk (yang diciptakan) sedangkan Tuhan adalah yang maha menciptakan (Al-Khaliq), sebagaimana dalam teks berikut:

"Ya, Tuhan yang menciptakan manusia" (Shirazy, 2019: 165).

Kutipan teks tersebut memiliki makna bahwasanya Tuhan sebagai pencipta, yang artinya memiliki kewenangan mutlak menghidupkan atau mematikan manusia.

“...Kepala dan muka adalah bagian paling mulia bagi manusia. Bagian yang paling mulia itu harus ditundukkan sepenuhnya dengan keikhlasan kepada Allah. Tidak ada yang lebih mulia dari Allah..." (Shirazy, 2019: 209).

Teks tersebut menggambarkan bagaimana bentuk penghambaan seorang manusia pada Tuhannya, Allah Swt. Doktor Anastasia merasa bahwa bersujud dan menempelkan kening ke lantai adalah bentuk ritual ibadah yang merendahkan manusia, dianggap primitif dan kolot. Namun, Ayyas membantah, bahwa sujud adalah bentuk penghambaan paling total yang dilakukan manusia. Selain itu, bentuk hormat antara manusia dengan Tuhan itu berbeda. Umat Islam 
hanya menyembah Allah Swt semata. Sujud hanya ditujukkan kepada yang maha merajai, Allah. Sujud tidak ditujukkan untuk yang lain, tidak untuk sesama manusia. Di sisi Allah manusia itu sama; yang membedakannya adalah taqwa.

Penggambaran perbedaan mutlak antara manusia dan Tuhan adalah dengan meyakini bahwa segala di dunia ini telah menjadi sunatullah. Manusia tak mempunyai kewenangan dalam mengatur kehidupan di muka bumi ini. Hanya saja, manusia selalu dianjurkan untuk mengusahakan hal-hal baik, dengan cara merencanakan sesuatu secara matangmatang, lalu diwujudkan dalam bentuk perbuatan, sebagai usaha untuk mewujudkan rencananya. Penggambaran tentang hal itu terdapat dalam kutipan berikut ini.

“...Ia hanya bisa merencanakan dan merancang, namun pada akhirnya Allahlah yang memutuskan hasilnya." (Shirazy, 2019: $58)$.

Tuhan mutlak berbeda dengan manusia. Hal itu merupakan kebenaran postulat yang tak terbantahkan. Jika manusia sebagai makhuk, Allah adalah sang khaliq, yang menciptakan. Dalam teks tersebut tergambar bahwa manusia hanya bisa merencanakan sesuatu, yang maha menentukan adalah Allah Swt.

\subsubsection{Pengakuan Adanya Norma-Norma Mutlak yang Tidak Berasal dari Akal Manusia}

Norma yang dimaksud berupa tata aturan dan hukum yang indikasinya mengarah pada dua aspek, yakni sesuatu yang diperintahkan dan sesuatu yang dilarang. Seperti yang terdapat dalam kutipan berikut ini.

"Ketika seseorang sujud kepada Allah, berarti dia siap melaksanakan seluruh perintah Allah dan siap untuk menjauhi seluruh larangan Allah. Artinya, di luar shalatpun dia siap sujud kepada Allah, patuh kepada Allah tanpa keraguan sedikitpun" (Shirazy, 2019: 209).

Kehidupan di dunia ini sudah diatur oleh Allah Swt, termasuk cara ibadah. Ibadah dalam Islam telah diatur sedemikian rupa oleh Allah sehingga manusia tidak bisa lagi menggagu gugat tata cara atau tata urutan dalam sebuah peribadatan. Salah satu contoh ibadah dalam Islam adalah salat. Melaksanakan salat adalah bentuk pengakuan atas perintah Allah Swt. Seorang muslim diwajibkan untuk menjalankan ibadah shalat fardu lima kali dalam sehari semalam. Dalam salat terdapat tata cara dan urutan yang sudah ditentukan Allah sedemikian rupa. Tidak ada yang bisa mengurangi atau melebihkan apa yang sudah ditetapkan Allah.

Dengan meyakini adanya norma-norma yang mutlak dari Tuhan, orang akan memperhatikan apa yang dikehendaki oleh Tuhannya, Allah Swt dan menjauhi apa yang dibenci-Nya. Perilakunya akan bertumpu pada keimanannya.

“...Tiba-tiba ia teringat bahwa tetap ada yang melihat, tetap saja ada yang menyaksikan apa yang akan dilakukannya dengan Linor, yaitu Allah yang maha melihat" (Shirazy, 2019: 369).

Ayyas ketika digoda oleh Linor Corsova untuk berbuat zina hampir saja menuruti, tetapi tidak jadi dilakukan karena ia meyakini bahwa Allah maha melihat apa yang akan diperbuatnya. Tindak tanduknya ia jaga karena itu bagian dari keyakinanya (nilai transendental), yakni beriman bahwa Allah Swt maha melihat dan maha mengetahui. Inilah perbedaan mutlak antara manusia dan Tuhan. Tuhan maha melihat dan maha mengetahui. Tuhan maha melihat dan maha mengetahui, sedangkan manusia memiliki keterbatasan. 
Teks tersebut menggambarkan suatu keyakinan seorang hamba (tu'minuna billah) bahwa Allah maha melihat dan akan mengganjar apa yang diperbuatnya di dunia ini kelak di akhirat. Ia takut untuk berzina dengan perempuan bernama Linor. Keyakinannya bahwa Allah maha melihat. Oleh karena itu, ia menjaga perbuatannya agar tidak terjerumus dalam perbuatan zina. Perbuatan zina ialah perbuatan yang keji.

Dan janganlah kamu mendekati zina; sesungguhnya zina itu adalah suatu perbuatan yang keji. Dan suatu jalan yang buruk (Q.S Al Isra' (17): 32).

Orang-orang mukmin akan memperhatikan perbuatannya karena adanya anjuran dan larangan dari Allah yang tertuang dalam kitab suci Al-Quran sebagai petunjuk bagi orang-orang mukmin.

\subsection{Dimensi Transendensi sebagai Dasar Kegiatan Humanisasi dan Liberasi}

Transendensi sebagai basis dari dua elemen profetik, yakni humanisasi dan liberasi. Berikut kutipan yang mengisyaratkan adanya dimensi transendensi sebagai dasar kegiatan humanisasi.

"Baiklah, mari kita selamatkan satu nyawa umat manusia malam ini semampu kita" (Shiarzy, 2019: 171).

"Salma tidak ragu untuk menolong perempuan Yahudi Lebanon, dan menyelamatkan nyawa perempuan itu dengan mendonorkan darahnya." (Shirazy, 2019: 404).

Dari dua kutipan ini menunjukkan landasan keimanan akan mempengaruhi perilaku. Ayyas yang mulanya ragu untuk menolong karena takut kejadian seperti di apartemennya terulang kembali. Ia berniat menolong orang, tetapi malah mendatangkan masalah baginya. Hal itu ia tepis dengan baik. Sebab, ia teringat pada Allah, ingatannya menuju pada perintah di dalam Al-Quran untuk menjaga hidup satu nyawa manusia.

Begitu juga dengan Salma yang menolong perempuan Yahudi lebanon. Hal itu tercermin dari nilai transendensinya yang meyakini bahwa apa yang diperintahkan Allah dalam kitab suci-Nya menjadi landasan dasar perbuatan humanisnya.

Barangsiapa yang membunuh seorang manusia, bukan karena orang itu (membunuh) orang lain, atau bukan karena membuat kerusakan dimuka bumi, maka seakan-akan dia telah membunuh manusia seluruhnya. Dan barangsiapa yang memelihara kehidupan seorang manusia, maka seolah-olah dia telah memelihara kehidupan manusia semuanya (Q.S. Al-Maidah (5): 32).

Setiap kehidupan umat manusia harus beralandas pada Al-Quran. Al-Quran mengatur seluruh tindak tutur, perilaku dan perbuatannya di muka bumi. Semua perbuatannya akan mendapat ganjaran dari Allah Swt di hari akhir. Rasulullah shalallahu 'alaihi wa sallam bersabda:

Barang siapa yang melepaskan satu kesusahan seorang mukmin, pasti Allah akan melepaskan darinya satu kesusahan pada hari kiamat. Barang siapa yang menjadikan mudah urusan orang lain, pasti Allah akan memudahkannya di dunia dan di akhirat. Allah senantiasa menolong hamba-Nya selama hamba-Nya itu suka menolong saudaranya. (H.R. Muslim).

Dimensi transendensi sebagai dasar kegiatan liberasi tertuang dalam kutipan berikut ini:

“....Dan setiap shalat subuh ia mengaji hadishadis nabi bersama pak Joko yang haus ilmu agama memang minta dijelaskan satu hadits dari kumpulan hadits Arba'in Nawawi setiap pagi. Tak terasa hadis Arba'in Nawawi sudah dikhatamkan. Dan Ayyas kini mulai menje- 
laskan hadis-hadis lain yang ia pilih dari kitab Riyadhush Sahalihin..." (Shirazy, 2019: 474). "Ayyas bertekad kuat, ia harus meninggalkan jejak amal saleh di Moskwa. Ia ingin meninggalkan bekas baik pada Shamil dan Sarah. Karenanya ia bertekad tidak akan meninggalkan Moskwa sebelum kedua anak Chechnya itu bisa membaca Al-Quran dengan baik, memahami akidah dengan benar dan mampu menjalankan ibadah sesuai tuntunan Baginda Nabi Saw" (Shirazy, 2019: 478).

Dua kutipan tersebut, menunjukkan bahwa transendensi menjadi dasar apa yang dilakukan oleh Ayyas. Liberasi dalam novel ini menjabarkan tentang memanusiakan manusia, membebaskan manusia dari kebodohan. Ada tiga amalan dalam Islam yang tidak akan putus pahalanya, di antaranya adalah ilmu yang bermanfaat. Imu yang bermanfaat maksudnya ialah ilmu yang disebarkan kepada orang lain dengan niat ibadah, ingin beramal saleh. Hal tersebut berdasarkan hadis nabi yang diriwayatkan oleh Muslim.

llmu yang bermanfaat, seperti mengajarkan sesuatu kepada orang lain atau murid. Dalam hal ini Ayyas mengajarkan ilmu kepada pak Joko tentang hadis-hadis nabi, agar pak Joko bisa memahami isi dari sunah nabi dan mengajarkan baca Al-Quran pada dua anak Chechnya, Shamil dan Sarah. Kegiatan liberasi yang dilakukan oleh Ayyas dalam teks tersebut didasarkan pada keyakinannya, berdasar nilai-nilai transendensi. Jadi terintegrasi antara ilmu, iman, dan amal.

\section{Simpulan}

Terdapat tiga unsur transendensi yang terkandung dalam novel Bumi Cinta karya Habiburrahman El Shirazy, seperti yang diungkapkan oleh Roger Garaudy, yakni pertama, pengakuan tentang ketergantungan manusia kepada Tuhan. Unsur ini mengungkap bahwa manusia menyadari bahwa dirinya sebagai hamba yang bergantung pada Tuhan. Hal tersebut dapat ditemukan dalam teks yang dinarasikan dalam bentuk doa dan zikir.

Kedua, ada perbedaan yang mutlak antara Tuhan dan manusia. Hal ini merupakan isyarat bahwa manusia ialah makhluk (yang diciptakan) dan Tuhan sebagai yang menciptakan (al-khaliq). Hal ini menjadi perbedaan yang paling fundamental antara manusia dan Tuhan. Manusia sebagai makhluk hanya bisa berencana, yang mentukan segalanya adalah Tuhan.

Ketiga pengakuan akan adanya normanorma mutlak dari Tuhan yang tak berasal dari akal manusia. Ada tata aturan dan hukum yang tak bisa dijangkau oleh akal manusia. Akan tetapi manusia wajib mematuhi perintah dan menjauhi larangan Allah.

Transendensi mendapatkan peranan penting dalam memberikan makna sekaligus mengarahkan tujuan hidup manusia. Dimensi transendensi menjadi dasar kegiatan humanisasi dan liberasi. Transendensi sebagai dasar kegiatan humanisasi tercermin dari sikap Ayyas yang menyelamatkan Yelena saat diambang kematian. Selain itu, transendensi sebagai dasar kegiatan humanisasi juga tergambar dari sikap Salma yang membantu Yahudi Lebanon tanpa meman-dang agama, karena ia meyakini kitab suci Al-Quran dan patuh terhadap isi Al-Quran. Dimensi transendensi menjadi dasar kegiatan liberasi tercermin dari perilaku tokoh Ayyas yang mengajarkan pak Joko tentang hadis-hadis nabi dan mengajar membaca Al-Quran pada anak-anak Chechnya, Shamil dan Sarah.

\section{Daftar Pustaka}

Alimatussa'diyah dan Nuryatin. 2017. "Inferioritas Tokoh Perempuan dalam Novel Bumi Cinta Karya Habiburrahman El Shirazy." Seloka: Jurnal Pendidikan Bahasa Dan Sastra Indonesia 6 (1): 15-24.

Asy'ari, Hasyim. 2018. “Renaisans Eropa Dan 
Transmisi Keilmuan Islam Ke Eropa." JUSPI: Jurnal Sejarah Peradaban Islam 2 (1): 1-14.

https:// doi.org/10.30829/j.v2i1.1792

Efendi, Anwar. 2012. "Realitas Profetik dalam Novel Ketika Cinta Bertasbih Karya Habiburrahman El Shirazy." Litera:Jurnal Penelitian Bahasa, Sastra, dan Pengajarannya 11(1):72-82. https://doi.org/10.21831/ltr.v11i1.1148

Garaudy, Roger. 1982. Janji-Janji Islam. Jakarta. Bulan Bintang.

Hadi, Abdul. 2016. Hermeneutika, Estetika, dan Religiusitas: Esai-esai Sastra Sufistik, dan Seni Rupa. Jakarta Selatan: Sadra press.

Hanafi, Hasan dkk. 2007. Islam dan Humanisme: Aktualisasi Humanisme Islam di Tengah Krisis Humanisme Universal. Yogyakarta: Pustaka Pelajar.

Kuntowijaya. 2006. Maklumat Sastra Profetik: Kaidah, Etika, dan Struktur Sastra. Bekasi: Multi Pressindo.

. 2001. Muslim tanpa Masjid: EsaiEsai Agama, Buadaya, dan Politik dalam Bingkai Strukturalisme Transendental. Bandung: Mizan.

1991. Paradigma Islam: Interpretasi untuk Aksi. Bandung: Mizan.

Moleong, Lexi. 2016. Metodologi Penelitian Kualitatif. Bandung: PT Remaja Rosdakarya.

Ricoeur, Paul. 2006. Hermeneutika Ilmu Sosial. Diterjemahkan Muhammad Syukri. Yogyakarta: Kreasi Wacana. (Buku asli diterbitkan 1981).
2012. Teori Interpretasi: Memahami Teks, Penafsiran, dan Metodologinya. Diterjemahkan Musnur Hery. Yogyakarta: IRCiSod.

Rifai, Aminudin. 2009. "Sastra Profetik Kuntowijoyo." Adabiyyāt: Jurnal Bahasa Dan Sastra 8 (1): 111-40. https://doi.org/10.14421/ajbs.2009.08106

Roqib. 2011. Prophetic Education: Kontekstualisasi Filsafat dan Budaya Profetik dalam Pendidikan. Purwokerto: STAIN Pres.

Shirazy, Habiburrahman El. 2019. Bumi Cinta. Jakarta: Republika.

Sumaryono. 1999. Hermeneutik, Sebuah Metode Filsafat. Yogyakarta: Kanisius.

Syam, N. W. 2015. Komunikasi Transendental: Perspektif Sains Terpadu. Bandung: Remaja Rosdakarya.

Uhi. 2016. Filsafat Kebudayaan: Konstruksi Pemikiran Cornelis Anthonie van Peursen dan Catatan Reflektifnya. Yogyakarta: Pustaka Pelajar.

Wachid Abdul, B.S. 2006. "Hermeneutika Sebagai Sistem Interpretasi Paul Ricoeur dalam Memahami Teks-Teks Seni. "Imaji: Jurnal Seni dan Pendidikan Seni 4 (2): 197-209.

Wirawan, Gunta. 2018. “Dimensi Transendensi Dalam Antologi Puisi Rahasia Sang Guru Sufi Karya Odhy's." DIALEKTIKA: Jurnal Bahasa, Sastra, dan Pendidikan Bahasa dan Sastra Indonesia, 5 (2): 196-218. https:/ / doi.org/10.15408/dialektika.v5i2.98 34 